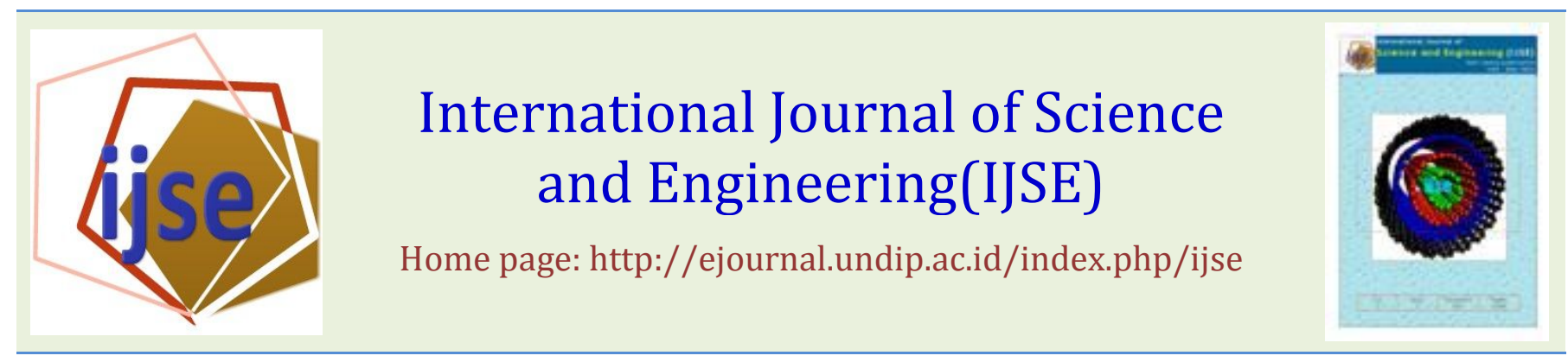

\title{
The Nutrient Potency of Palm Oil Plantation and Mill's By-product Processedwith Amofer Technology as Ruminant Feed
}

\author{
Hamdi Mayulu1) \\ 1)Animal Sciences Department of Agricultural Faculty, Mulawarman University \\ Jl. Pasir Belengkong Kampus Gunung Kelua Samarinda 75123 \\ Email: mayoeloehsptno@yahoo.com
}

\begin{abstract}
By-product derived from palm oil plantation and mill is very potential for energy and protein source for ruminant feed. However, it is still underutilized due to low content of crude protein (CP) with high crude fiber (CF). Ammoniation or fermentation technology could optimize the quality of by-product by increasing digestibility, reducing $C F$ and increasing CP content. The objective of this research was to determine the nutrient and potency value of palm oil plantation and mill's by-product applied with amofer technology for ruminant feed. Sample was prepared in two methods: 1) sample without amofer application, 2) sample with amofer application under anaerobic method and incubated for 18 days. Ammoniation was carried out by adding urea of 3\% from the total material and then incubated for nine days. At the ninth day, some microorganisms starter i.e. cellulolytic, amillolytic and proteolytic were added by $1 \%$ of the total material. Proximate analysis was carried out in laboratory to examine the nutrient value. The crude protein content at each part of feed material before and after amofer treatment was follow: palm midrib: 3.16\%:17\%; palm leaves 6.53\%:26.51\%; empty fruit bunch 7.01\%:1673\%; palm pressed fiber 5.56\%:16.00\%. While the crude fiber at each part of feed material was: palm midrib 37.85\%:30.86\%; palm leaves 30.39\%:24.41\%; EFB 40.22\%:34.98\%; PPF 50.39\%: 41.70\%. The application of amofer could increase the amount of feed material (ton/ha/y): dry matter (DM) 14.82:15.89; CP 0.79:2.87; total digestible nutrient (TDN) 7.63:8.5. Moreover, amofer application could also increase the nutrient content of palm oil plantation and mill's by-product by increasing CP and reducing CF. This increasing was also followed by the increasing of DM, CP, and TDN which indicated that those feed sources were recommended as ruminant feed material.
\end{abstract}

Keywords:By-product amofer, urea, anaerobic, nutrient, ruminant(;)

Submission: December 28, 2013

Correction: March 25, 2014

Accepted: April 2, 2014

Doi: 10.12777 ijse.6.2.112-116

[How to cite this article: Mayulu, H. 2014. The Nutrient Potency of Palm Oil Plantation and Mill's By-product Processed With Amofer Technology As Ruminant Feed, International Journal of Science and Engineering, 6(2),112-116. Doi:10.12777/ijse.6.2.112-116]

\section{INTRODUCTION}

Optimization the uses of plantation area could be one effort to provide adequate amount of site specific feed for ruminant either in integration or diversification pattern. Crop livestock system is recognized as mutualism system as it increases the fertility both plant and soil. These fertility lead to the increasing of feed production over year and then subsequently increase the production and productivity of livestock (Riady, 2004; Kusnadi, 2008; Mayulu et al., 2010; Sunarso et al., 2011).

Utilization of palm oil by-product as high economic value feed source is a useful alternative and could reduce the environmental impact generated by palm oil. This is also recognized as an efficient method to produce economic product. Various researches stated that palm oil by-product is very potential for energy and protein source for ruminant. However, it still has low quality due to low content of crude protein (CP) with high crude fiber (CF) (Sutrisno, 2001; Sutrisno, 2002; Agricultural Research and Development, 2005; Harfiah, 2007).

Generally, forage produced in Indonesia has low quality which could not yield maximum productivity of livestock due to insufficient amount of energy, protein and mineral. Using technology approach, many of palm oil plantation and mill's by-product is potential to be utilized for ruminant feed source. Recent technology has shown the promising development of complete feed formulation based palm oil plantation and mill's by-product. The quality of palm oil plantation and mill's by-product could be optimized using ammoniation or fermentation method to increase the digestibility by reducing $\mathrm{CF}$ and increasing $\mathrm{CP}$. Some previous researches reported that fermentation of palm kernel (PK) and palm oil sludge (POS) could 
increase CP up to $67 \%$ and reduced CF to $27 \%$ (Sutrisno, 200; Hardianto, 2003; Umiyasih and Anggraeni, 2007; Puastuti, 2008).

Ammoniation fermentation (amofer) is recognized as an applied technology where a combination of ammoniation and fermentation are carried out together with certain method and technique which uses urea and cellulolytic, amillolytic and proteolytic microorganism. Cellulolytic microorganism degrades complex carbohydrate of $\mathrm{CF}$, amillolytic degrades simple carbohydrate and proteolytic degrades protein. Together, urea used in ammoniation process and microorganism used in fermentation process work to reduce $\mathrm{CF}$ and increase CP of feedstuff. This condition is closely related to the increased digestibility rate at the beginning of digestive process that affects the energy availability of adenosine triphosphate (ATP) which required during rumen microbial proliferation (Mayulu, 2012; Sudarmono, 2013).

Ammoniation has several advantages such as simple procedure, harmless, cheaper and easier to make compared to $\mathrm{NaOH}$, effective to remove aflatoxin especially in rice straw, could increase $\mathrm{CP}$ and does not have pollution effect. The only one $\mathrm{NH}_{3}$ substance which is cheap and easy to get is urea. Fertilizer is the common used of urea. Urea in the form of $\mathrm{CO}\left(\mathrm{NH}_{2}\right)_{2}$ is commonly used substance to formulate ruminant feed due to the availability, cheap and less toxicity compared to biuret. The physical form of urea is white color and hygroscopic. Urea contains nitrogen of $42-45 \%$ which equal to $\mathrm{CP}$ ranges from 262-281\%. Three kinds of ammonia sources that can be used are $\mathrm{NH}_{3}$ in the form of liquid gas (anhydrous), $\mathrm{NH}_{4} \mathrm{OH}$ in the form of solution (aqueous) and urea in the form of solid $\mathrm{CO}\left(\mathrm{NH}_{2}\right)_{2}$. Among of those three sources, urea is the most widely used. Urea is recognized as nitrogen source that can be fermented. Urea contains $46 \%$ nitrogen so that $1 \mathrm{~kg}$ urea equals to $2.88 \mathrm{~kg} \mathrm{CP}(6.25 \times 46 \%)$ and the hydrolysis yields $0.57 \mathrm{~kg}$ ammonia gas (Caneque et al., 2000; Ribeiro, 2000; Andajani, 2010).

Fermented palm oil plantation and mill's by-product could run effectively if certain microbe is added as inoculant. Some effective inoculant or fermenter for plantation waste fermentation is Aspergilus niger, Tricoderma and Rhizoplus. Aspergilus niger is a facultative fungus which can growth under aerobic or anaerobic environment. Thus, the uses of this fungus will be more practical since fermentation process does not require closed system (Wina, 2005; Akbar, 2007). Application Aspergilus niger for fermentation process has been widely used in Animal Research Center in Ciawi, Bogor. This fermentation process increased CP from $12.2 \%$ to $24.5 \%$ DM and metabolic energy also increased from $1.6 \mathrm{kkal} / \mathrm{g}$ to $1.7 \mathrm{kkal} / \mathrm{g}$. The application of fermentation technology still needs to be improved in order to optimize the nutrient content of feedstuff (Guntoro, 2005; Mathius et al., 2004; Wina, 2005; Mathius, 2008).

This research was aimed to determine the nutrient content and potency of by-product derived from palm oil plantation and mill processed with amofer technology as an alternative ruminant feed source.

\section{RESEARCH METHOD}

Sample consisted of palm midrib, leaaves, Centrosema $s p$., empty fruit bunch (EFB), palm pressed fiber (PPF), palm kernel (PK), and palm oil sludge (POS). All samples was obtained from PTPN XIII, Long Ikis district, Paser regency, East Kalimantan province. Sample preparation was carried out directly in the field site and transported to the Laboratory of Animal Nutrient and Feed, Faculty of Animal and Agriculture, University of Diponegoro. Sample was arranged into two groups: 1) First, sample without amofer treatment, and 2) second, sample including palm midrib, leaves, EFB and PPF were treated with amofer (Fig. 1). The first sample was carried out to examine the original nutrient of site specific material.

The first step was to mill all sample material using 0.5 mm sieve grinder. Proximate analysis was carried out to determine the nutrient composition and proportion of sample material consisting palm midrib, leaves, Centrosema sp., EFB, PK, and POS. Centrosema sp., PK and POS did not experience amofer treatment due to high nutrient amount of $\mathrm{CP}$.

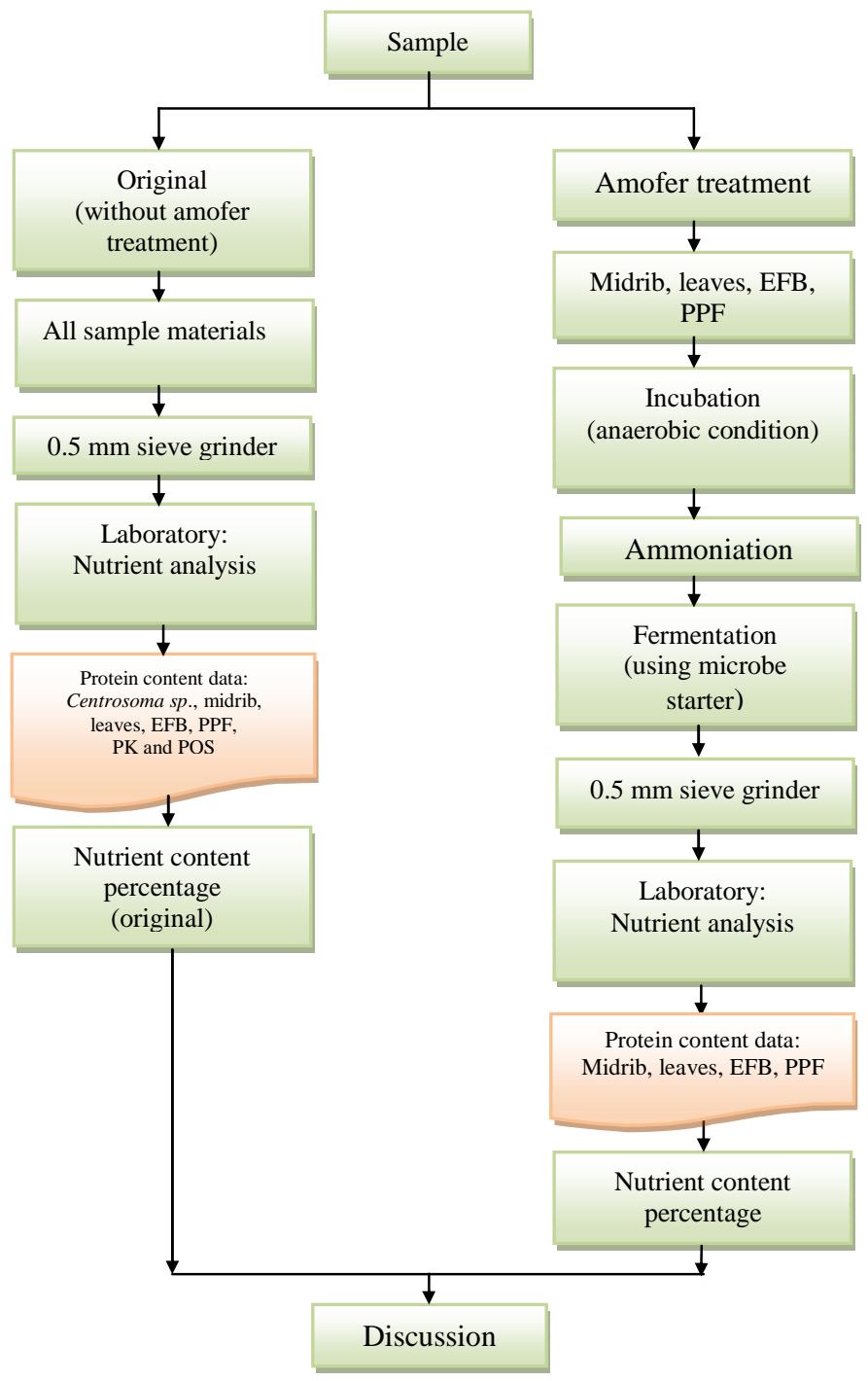

Figure 1. Research Flow Chart

Sample including palm oil midrib, leaves, EFB and PPF experienced amofer treatment to increase the nutrient 
content. Amofer process with anaerobic incubation was carried out using black plastic sizes of $100 \times 85 \mathrm{~cm}$. Fermentation was carried out for 18 days under these following steps: 1) Ammoniation using urea supplementation by $3 \%$ from total material at the first day of treatment (Musalia et al., 2000) and then incubated for nine days in plastic with 25-30 kg capacity; 2) Fermentation, microbe starter such as cellulolytic microorganism, amilolytic and proteolytic was added at the ninth day by $1 \%$ of the total material and then incubated. Adequate water was added during amofer process. The palm midrib, leaves, EFB, and PPF were then removed from plastic and tempered after completing amofer process. The next step was to mill the material using $0.5 \mathrm{~mm}$ sieve grinder to obtain uniform size and surface area. The following step was proximate analysis to determine the nutrient value of material.

\section{III.RESULT AND DISCUSSION}

Exploration of feed source derived from palm oil plantation and mill gains attention for providing sufficient amount for ruminant feedstuff. Those could be conducted by direct utilization or processed using amofer technology (Fig. 2). Proximate analysis showed that feedstuff without amofer technology had sufficient nutrient amount ranging from $3.16-17.86 \%$ of CP. In term of DM, CP, and TDN; the result showed that by-product materials derived from palm oil plantation and mill were potential for feed source (Table 1).
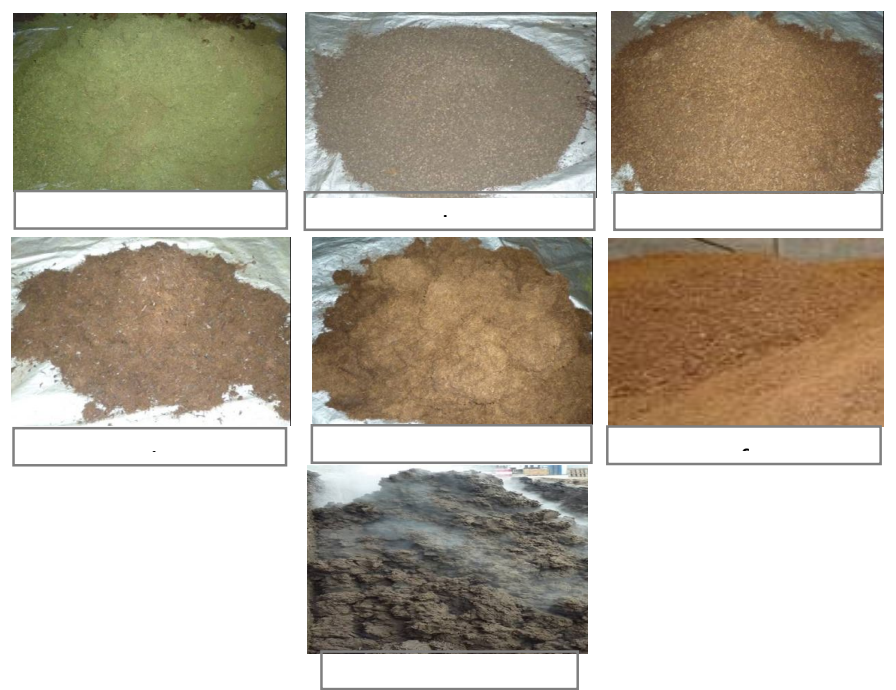

Fig 2. Palm oil plantation and mill's by-product as feed material (a. Centrosoma sp.; b. Palm leaves; c. Palm midrib; d. Palm empty fruit bunches; e. Fiber fruit juice; f. Palm kernel and g. Palm oil sludge

Table 1. Original Nutrient of Palm Oil Plantation and Mill's By-product (Mayulu et al., 2013)

\begin{tabular}{|c|c|c|c|c|c|c|c|c|}
\hline \multirow{2}{*}{ Feed material } & \multicolumn{8}{|c|}{ Nutrient composition (\%) } \\
\hline & Water $^{1}$ & $\mathrm{DM}^{1}$ & Ash $^{1}$ & Crude fat ${ }^{1}$ & $\mathrm{CF}^{1}$ & $\mathrm{CP}^{1}$ & BETN & $\mathrm{TDN}^{2}$ \\
\hline Palm midrib & 37.62 & 62.38 & 3.63 & 3.50 & 37.85 & 3.16 & 51.86 & 51.32 \\
\hline Palm leaves & 39.60 & 60.40 & 10.36 & 1.95 & 30.39 & 6.53 & 50.77 & 56.20 \\
\hline Centrosema sp. & 64.18 & 35.82 & 10.89 & 4.30 & 5.12 & 22.58 & 27.11 & 49.67 \\
\hline Empty fruit bunch & 35.40 & 64.60 & 12.09 & 1.14 & 40.22 & 7.01 & 39.54 & 46.92 \\
\hline Palm pressed fiber & 34.56 & 65.44 & 5.78 & 3,18 & 50.36 & 5.56 & 35.12 & 40.45 \\
\hline Palm kernel & 5.06 & 94.94 & 3.19 & 7,86 & 10.45 & 15.49 & 63.01 & 82.53 \\
\hline Palm oil sludge & 45.89 & 54.11 & 15.79 & 6.06 & 45.99 & 17.86 & 14.31 & 47.81 \\
\hline
\end{tabular}

${ }^{1}$ Proximate analysis result conducted in Animal Nutrient and Feed Laboratory, Faculty of Animal and Agriculture, Diponegoro University

${ }^{2}$ Calculation result Sutardi (2001)

Feedstuff including palm oil midrib, leaves, EFB and PPF were treated with amofer technology. While others materials including CP and POS did not experience amofer treatment due to higher nutrient content. Amofer technology increased nutrient and CP content and reduced CF content of feedstuff (Table 2). This result also has implication for the improvement of nutrient potency and carrying capacity of feed resource derived from palm oil plantation and mill's by-product.
Table 2. Analysis Result of Ammoniated and Fermented Feedstuff

\begin{tabular}{|l|c|c|c|c|c|c|c|c|}
\hline \multirow{2}{*}{ Feedstuff } & \multicolumn{7}{|c|}{ Nutrient composition (\%) } \\
\cline { 2 - 10 } & Water ${ }^{1}$ & $\mathrm{DM}^{1}$ & $\mathrm{Ash}^{1}$ & $\begin{array}{c}\text { Crude } \\
\text { fat }\end{array}$ & $\mathrm{CF}^{1}$ & $\mathrm{CP}^{1}$ & $\mathrm{BETN}^{1}$ & $\mathrm{TDN}^{2}$ \\
\hline Palm midrib & 35.84 & 64.16 & 5.36 & 3.02 & 30.86 & 17.00 & 43.77 & 58.94 \\
\hline Palm leaves & 35.08 & 64.92 & 5.62 & 1.80 & 24.41 & 26.51 & 41.65 & 61.40 \\
\hline $\begin{array}{l}\text { Empty fruit } \\
\text { bunch }\end{array}$ & 34.34 & 65.66 & 14.65 & 4.89 & 34.98 & 16.73 & 28.75 & 56.13 \\
\hline $\begin{array}{l}\text { Palm } \\
\text { pressed } \\
\text { fiber }\end{array}$ & 26.58 & 73.42 & 6.33 & 4.14 & 41.70 & 16.00 & 31.82 & 50.39 \\
\hline
\end{tabular}


In term of DM, CP and TDN, by-product derived from palm oil plantation and mill without amofer treatment was potential for ruminant feed source but not as good as feed material with amofer treatment. The analysis result is shown in Table 3.

Table 3. Dry Matter, Crude Protein and Total Digestible Nutrient content of Palm Oil Plantation and Mill's By-product in PTPN XIII East Kalimantan (Mayulu et al., 2013).

\begin{tabular}{|l|r|r|r|r|r|r|}
\hline \multirow{2}{*}{ By product } & \multicolumn{1}{|c|}{$\begin{array}{c}\text { Dry } \\
\text { Matter }\end{array}$} & \multicolumn{1}{|c|}{$\begin{array}{c}\text { Crud } \\
\text { Protein }\end{array}$} & & \multicolumn{1}{|c|}{$\begin{array}{c}\text { Total } \\
\text { Digestible } \\
\text { Nutrien }\end{array}$} & \\
\cline { 2 - 7 } & ton/ha/y & $\begin{array}{r}\text { Proportional } \\
\text { average (\%) }\end{array}$ & ton/ha/y & $\begin{array}{c}\text { Proportional } \\
\text { average (\%) }\end{array}$ & ton/ha/y & $\begin{array}{r}\text { Proportional } \\
\text { average (\%) }\end{array}$ \\
\hline Palm midrib & 8.76 & 59.09 & 0.28 & 35.27 & 4.49 & 58.92 \\
\hline Palm leaves & 1.53 & 10.31 & 0.10 & 12.72 & 0.94 & 12.29 \\
\hline Centrosema sp. & 0.37 & 2.48 & 0.08 & 10.60 & 0.18 & 2.40 \\
\hline $\begin{array}{l}\text { Empty fruit } \\
\text { bunch }\end{array}$ & 3.62 & 24.41 & 0.25 & 32.32 & 1.70 & 22.25 \\
\hline $\begin{array}{l}\text { Palm pressed } \\
\text { fiber }\end{array}$ & 0.18 & 1.23 & 0.01 & 1.29 & 0.07 & 0.96 \\
\hline Palm kernel & 0.19 & 1.29 & 0.03 & 3.77 & 0.16 & 2.06 \\
\hline $\begin{array}{l}\text { Palm oil } \\
\text { sludge }\end{array}$ & 0.18 & 1.20 & 0.03 & 4.04 & 0.08 & 1.11 \\
\hline Total & 14.82 & 100 & 0.79 & 100 & 7.63 & 100 \\
\hline
\end{tabular}

Ammoniation-fermentation on palm midrib, leaves, EFB and PPF increased the content of DM, CP and TDN. The application of amofer not only increased the quality but also increased the quantity. This could be seen in DM which increased from 14.82 to 15.89 ton/ha/y; CP from 0.79 to 2.87 ton/ha/y and TDN from 7.63 to 8.51 ton/ha/y. This increment associated with the increasing of weight due to supplementation of urea and microbe starter even with insignificant amount (Table 4).

Palm leaf without amofer treatment had lower quality and its rough characteristic had no advantage for animal. Ammoniation, molasses addition, alkali, silage formulation, high vapor pressure, pallet and enzymatic process are proven technologies to increase the nutrient amount and biological quality of palm midrib (Batubara et al., 2003; Ginting and Elisabeth, 2004; Azmi and Gunawan, 2006; Mahgoub, et al., 2007).

Table 4. The content of DM, CP and TDN of Palm Oil Plantation and Mill's By-product Processed with Amofer Technology

\begin{tabular}{|c|c|c|c|c|c|c|}
\hline \multirow[b]{2}{*}{ By product } & \multicolumn{2}{|c|}{ DM } & \multicolumn{2}{|c|}{ CP. } & \multicolumn{2}{|c|}{ TDN } \\
\hline & $\begin{array}{c}\text { ton/ha/ } \\
\mathrm{y}\end{array}$ & $\begin{array}{l}\text { Proportiona } \\
\text { laverage } \\
(\%)\end{array}$ & $\begin{array}{c}\text { ton/ha/ } \\
\mathrm{y}\end{array}$ & $\begin{array}{c}\text { Proportiona } \\
\text { laverage } \\
(\%)\end{array}$ & $\begin{array}{c}\text { ton/ha/ } \\
\mathrm{y}\end{array}$ & $\begin{array}{c}\text { Proportional } \\
\text { average }\end{array}$ \\
\hline Palm midrib & 9.38 & 59.05 & 1.59 & 55.56 & 4.88 & 57.42 \\
\hline Palm leaves & 1.71 & 10.78 & 0.45 & 15.82 & 0.95 & 11.15 \\
\hline EFB & 3.83 & 24.12 & 0.64 & 22.34 & 2.15 & 25.29 \\
\hline PPF & 0.22 & 1.39 & 0.04 & 1.23 & 0.09 & 1.10 \\
\hline PK & 0.19 & 1.22 & 0.03 & 1.05 & 0.16 & 1.89 \\
\hline POS & 0.18 & 1.12 & 0.03 & 1.10 & 0.08 & 1.00 \\
\hline Centrosema sp. & 0.37 & 2.32 & 0.08 & 2.90 & 0.18 & 2.15 \\
\hline Total & 15.89 & 100 & 2.87 & 100 & 8.51 & 100 \\
\hline
\end{tabular}

According to Mathius (2003) and Hanafi (2004), the addition of urea had higher capability to increase the content of DM, CP and digestibility of silage-based palm leaf compared to silage without urea application. Its application on cattle could increase the DM content by 45\%. Moreover, Batubara, (2003), Mathius et al. (2004) and Utomo (2004) also stated other advantages of urea application in ammoniation process i.e. ease procedure and could increase the nutrient value of feedstuff. Palm leaf with ammoniation process could increase crude protein content $\pm 2.0 \%$ and digestibility by $4-5$ times. Silage with addition of urea or molasses has not given satisfactory result although it could increase the nutrient value.

Ammoniation method using ammonia gas, hydroxide ammonia or urea to increase the digestibility of cattle is regarded as an applicable method. Adequate supply of ammonia nitrogen $\left(\mathrm{NH}_{3} \mathrm{~N}\right)$ in rumen is required to optimize the digestibility of low quality fermented feed that will support the growth of rumen microbe. Urea has been widely applied by individual farmer or enterprise in small scale farming particularly in development country. Reducing urea application from 4 to $2 \%$ and combined with hydroxide calcium $0.5 \%$ will give lower rumen degradation compared to ammonia treatment. However, this treatment gives higher added value (Galina et al., 2004; Elseed, 2005).

Urea is recognized as good protein source for cattle and sheep's offspring growth. In accordance with Musalia et al. (2000), this research used urea 3\% for protein source in ammoniation process of CP. Haryanto et al. (2001) also proved that urea $3 \%$ in ammoniation process of fermented dried cassava waste pulp could increase nitrogen balance and energy digestibility of sheep.

Addition of particular microbe as inoculant is required to increase the effectiveness of fermentation process of palm oil plantation and mill's by-product. During fermentation process, microorganism produces such of enzyme which activate chemical reaction. This changes complex molecule or organic compound such as protein, carbohydrate and fat into simpler molecule that are easily digested. Fermentation also changes other nutrient compound such as amino acid and vitamin on the raw material. Fermentation could produce better aroma, increase the shelf life and reduce the toxic content of raw material that would give higher economic value (Nirwana, 2005; Oji et al., 2007).

Ammoniated-fermented feedstuff including palm midrib, leaves, EFB and PPF together with nonammoniated-fermented material including CP, POS and Centrosema sp. could be made into $\mathrm{CF}$ with addition of corn, rice bran, dried cassava waste pulp, molasses, urea mineral and salt. According to Mayulu et al. (2012), all feed material derived from palm oil plantation and mill's by-product that were used for CF $40 \%$ with protein level $14 \%$ was very palatable and did not give negative effect on blood profile and kidney function of local sheep. Thus, it is recommended as an alternative source for site specific feedstuff.

\section{CONCLUSION}

Ammoniated-fermentation treatment increased the nutrient content of palm oil plantation and mill's byproduct which showed by the increasing content of protein and decreasing content of crude fiber. This increasing was followed by the increasing of DM, CP and TDN. Thus, it was recommended to use this feedstuff as ruminant feed source.

\section{REFERENCES}

[1] Akbar, S. A. 2007. Utilization of fermented palm bunches trash combined with defaunation and rumen by pass protein on sheep performance. Journal of the Indonesian Tropical Animal Agriculture 32 (2): 80-85. 
[2] Andayani, J. 2010. Evaluation of dry matter, organic matter and crude protein in vitro digestibilities of ammoniated corn husk in cattle ration. Journal of Livestock Sciences XIII (5): 252-259.

[3] Azmi and Gunawan. 2005. Potency of forage plantation area for the development of beef cattle in Bengkulu. $\underline{I n}$ : Subandriyo, K. Diwyanto, I. Inounu, B. R. Prawiradiputra, B. Drtiadi, Nurhayati and A. Priyanti. Proceeding of the National Workshop on Animal Forage. Bogor 16 September 2005. pp. 64-67.

[4] Agricultural Research and Development. 2005. Prospect and target of the development of cattle agribusiness. Department of Agriculture, Jakarta.

[5] Batubara, L. P. 2003. Potential of animal production integrated with palm oil estate as an agribusiness based ruminant. Wartazoa13 (3): 83-91.

[6] Batubara, L., S. P. Ginting, K. Simanihuruk, J. Sianipar and A. Tarigan. 2003. Utilization of palm oil waste and by-product for sheep ration Proceeding of the National Seminar on Animal and Veterinary Technology. Centre of research and development of livestock. Bogor. pp. 106-109.

[7] Caneque, V., S. Valasco and J. L. Sanca. 2000. Nutrional value use of ligno-cellulosic feed treated with urea in the ruminant diet. Options Mediterraneennes Serie Seminaires 16 (1991): 17-31.

[8] Elseed, F. A. M. A. 2005. Effect of supplemental protein feeding frequency on ruminal characteristics and microbial $\mathrm{N}$ production in sheep fed treated rice straw. Small Ruminant Research 57: 11-17.

[9] Galina, M. A., J. D. Hummel, M. Sánchez and G. F. W. Haenlein. 2004 Fattening Rambouillet lambs with corn stubble or alfalfa, slow intake urea supplementation or balanced concentrate. Small Ruminant Research 53: 89-98.

[10]Ginting, S. P and J. Elisabeth. 2004. Technology of feed-based byproduct of palm oil plantation. Proceeding of National Workshop. Bengkulu, September 9-10 th 2003. Department of Agriculture in cooperation with Provincial Government of Bengkulu and PT. Agricinal.

[11]Guntoro, S. 2005. Processing plantation waste for livestock feed source. Warta Prima Tani1 (1): 8-11.

[12]Hanafi, N. D. 2004. Silage and ammoniation treatment of palm leaves as feed source for sheep. Program study of livestock production, Faculty of Agriculture, Sumatera Utara University, Digitized by USU digital library.

[13]Hardianto, R. 2003. Complete feed formulation technology. In: G. Kartono, Suhardjo, E. Widajati and D Ernawanto (ed). Technical Guide for the Development of Agricultural Technology. Office of Agriculture Technology Application of East Java. p. 109-117.

[14]Harfiah. 2007. Dried palm oil sludge as the nutrient source of ruminant feed. Bulletin of Nutrient and Livestock Feed 6 (2): 27-30.

[15]Haryanto, B., N. Hidayat and M. Bata. 2001. The influence of urea and sulfur level on the nitrogen balance and energy digestibility of sheep fed by fermented dried cassava waste pulp and tofu. Animal Production 3 (2): 91-97.

[16]Kusnadi, U. 2008. Innovation on livestock technology in plantlivestock integration system to support meat self-sufficiency. Development of Agricultural Innovation1 (3): 189-205.

[17]Mahgoub, O., I. T. Kadim, M. H. Al-Busaidi, K. Annamalai and N. M. Alsaqri. 2007. Effects of feeding ensiled date palm fronds and a byproduct concentrate on performance and meat quality of Omani sheep. Animal Feed Science and Technology 135: 210-221.

[18]Mathius, I. W. 2008. Development of beef cattle based palm oil industry. Development of Agricultural Innovation1 (3): 206-224.

[19]Mathius, I. W., D. Sitompul, B. P. Manurung and Azmi. 2004. Byproduct of palm oil plantation and mill as complete feed source for cattle: a review. Proceeding of National Workshop. Department of Agriculture.
[20]Mathius, I. W. 2003. Palm oil plantation as a basis of beef cattle development. Bulletin of Agricultural Research and Development 25 (5): $1-4$.

[21]Mayulu, H., Sunarso, C. I. Sutrisno, Sumarsono. M. Christiyanto and K. Isharyudono. 2013. Potency of palm oil plantation and mill byproduct as ruminant feed in Paser Regency, East Kalimantan. J. of Sci. and Eng. 5 (2):56-60.

[22]Mayulu, H., Sunarso, C. I. Sutrisno and Sumarsono. 2012. The effects of amofer palm oil waste-based complete feed to blood profiles and liver function on local sheep. Internat. J. of Sci. and Eng 3 (1):17-21.

[23]Mayulu, H., Sunarso, C. I. Sutrisno and Sumarsono. 2010. Policy on the development of beef cattle in Indonesia. Journal of Agricultural Research and Development 29 (1): 34-41.

[24]Musalia, L. M., S. Anandan, V. R. Sastri and D. K. Agrawal. 2000. Ureatreated neem (Azadirachtaindica A. juss) seed kernel cake as a protein supplement for lambs. Small Ruminant Research 35: 107116.

[25]Nirwana. 2005. Effect of fermented cocoa peel used in concentrate on body weigth gain of local sheep. J. Agrisains 6 (3): 177-183.

[26]0ji, U. U., H. E. Etim and F. C. Okoye. 2007. Effects of urea and aqueous ammonia treatment on the composition and nutritive value of maize residues. Small Ruminant Research 69: 232-236.

[27]Puastuti, W. 2008.0ptimization of palm oil by-product as ruminant feed source. Seminar on the optimization of palm oil plantation and mill's by-product as livestock feed source. [Cited June $2^{\text {nd }} 2012$ ]. Available in: http:// peternakan.litbang.deptan.go.id/fullteks/lokakarya/plimbah08-21. pdf

[28]Riady, M. 2004. Challenges and opportunity of beef cattle production towards 2020. In: Setiadi B. et al., Editor. Proceeding of National Workshop on Beef Cattle. Yogyakarta October 8-9 $9^{\text {th }} 2004$. Center of Livestock Research and Development. Bogor. pp: 3-6.

[29]Ribeiro, J. M. C. R. 2000. Treatment of straws. Options Mediterraneennes Serie Seminaires 16 (1991): 55-60.

[30]Sudarmono. 2013. A success story on formulating prebiotic for fisheries, livestock and agriculture (Modern livestock series). Published by Pustaka Baru Press, Yogyakarta.

[31]Sunarso, L.K. Nuswantara, A. Setiadi and Budiyono. 2011. The performance of beef cattle fed by complete feed. International Journal of Engineering \& Technology IJET-IJENS 11 (01): 260-263.

[32]Sutrisno, C. I. 2002. The role of agricultural waste in the development of ruminant (Professor Inauguration Speech at University of Dipponegoro dated February $9^{\text {th }}$ 2002). Published by University of Diponegoro, Semarang.

[33]Sutardi, T. 2001. Revitalization of dairy cattle through utilization of ration based estate by-product and organic mineral supplement. Research of RUT VIII.1. Ministry of Research and Technology together with Indonesian Institute of Science, Bogor.

[34]Sutrisno, C. I. 2001. Integration of technology engineering and its implementation. Journal of Topical Livestock Development. Special Edition: KS 1-9.

[35]Umiyasih, U and Y. N Anggraeni. 2003. Integrated system of animal and plantation: review of the forage availability for beef cattle in palm oil plantation area. pp. 156 - 166. [Cited June $2^{\text {nd }} 2012$ ]. Available in: http:// peternakan.litbang.deptan.go.id/fullteks/lokakarya/probklu0316.pdf

[36]Utomo, R. 2004. A review on research results of beef cattle feed.Wartazoa 14 (3): 116-124.

[37]Wina, E. 2005.Technology on utilizing microorganism in feed to increase ruminant productivity in Indonesia: a review. Wartazoa 15 (4): 173-186. 